\title{
DRY MATTER PRODUCTION AND PARTITIONING OF MAIZE HYBRIDS AND DWARF UNES AT FOUR PLANT POPULATIONS
}

\author{
PRODUÇÃO E DISTRIBUIÇÃO DE MATÉRIA SECA DE HÍBRIDOS E LINHAGENS \\ ANÃS DE MILHO EM QUATRO POPULAÇÕES
}

\author{
Luis Sangoi $^{1}$ Ricardo Salvador ${ }^{2}$
}

\section{SUMMARY}

This experiment was conducted in Ames, Iowa, USA to compare dry matter accumulation patterns of maize genotypes contrasting in height and leafiness, and to test whether reduction in plant height an leaf number through the use of dwarfing genes or earliness can improve grain dry matter allocation. Five plant genotypes were tested: a full season hybrid adapted to central lowa (NK 4525), a short season hybrid adapted to northern Minnesota (C1070), and three dwarf lines (156-A, 302-E and I17A). The dwarves contained, respectively, the homozygous, independent, recessive dwarfing genes $d_{3}, d_{1}$ and $b r_{2}$. Each genotype was sown at four plant populations: 25, 50, 75 and 100.000 plants. $\mathrm{h}^{-1}$. Hybrids had the greatest rates of decrease in total biomass and grain dry matter per plant when population was increased, though they also had larger absolute values of these variables at any given density. Hybrids produced more grain dry matter per unit of leaf area, and a higher harvest index, regardless the plant population used. Reduction in plant height or leaf number did not improve maize efficiency in producing and partitioning dry matter to the grain.

Key words: Zea mays, plant height, density, harvest index.

RESUMO

Este experimento foi conduzido em Ames, Iowa, Estados Unidos, tendo como objetivos comparar os padrões de produção e distribuição de matéria seca de genótipos de milho contrastantes quanto a estatura e número de folhas, e verificar se a redução nestas características, mediante a utilização de genes para nanismo ou cultivares precoces, pode aumentar a eficiência da planta em alocar matéria seca para a produção de grãos. Cinco genótipos foram testados: um híbrido de ciclo normal adaptado à região central de lowa (NK 4525), um híbrido de ciclo precoce adaptado à região norte do estado de Minnesota $(C$ 1070), e três linhagens anãs (156-A, 302-E and 117-A), contendo os genes recessivos de nanismo $d_{3}, d_{1}$ and $b r_{2}$, respectivamente Cada genótipo foi semeado em quatro populações, equivalentes a 25, 50, 75 e 100,000 plantas.ha ${ }^{-1}$. Os híbridos tiveram maiores laxas de redução na matéria seca dos grãos do que as linhagens anãs com o aumento na população. Contudo, eles também apresentaram maiores valores absolutos para esta variável do que os materiais de porte baixo em todas as densidades avaliadas. Os híbridos produziram maior quantidade de matéria seca de grãos por unidade de área foliar e maior índice de colheita do que as linhagens anãs. A redução na estatura ou número de folhas por planta não aumentou a eficiência do milho em alocar matéria seca para a produção de grãos.

Palavras-chave: Zea mays, estatura de plantas, densidade, indice de colheita.

\section{INTRODUCTION}

Plant height is probably the most conspicuous trait subjected to natural selection in crops. Even slight superiority in height can give a plant, through advantageous competition for light,

${ }^{1}$ Engineer Agronomy, PhD., and Professor of the Department of Crop Production, Santa Catarina State University, P. O. BOX 281,

88520-000, Lages - SC. Author for correspondence.

${ }^{2}$ Engineer Agronomic, PhD., Professor of the Department of Agronomy, Iowa State University. 
sufficient yield increment to ensure dominance over its neighbors. This pattem has been reported for the major cereal crops in the literature (PENDLETON \& SEIF, 1962; JENNINGS, 1964; FISCHER \& TURNER 1978). Therefore, annual cereals became tall probably quite early in their cropping history. Tallness had certain advantages for early cereal cultivators, and such advantages can still be important for some subsistence agricultural systems around the world. Plant height provides stem material for feed, meal, bedding, building and thatching purposes; it may be an advantage when competition with weeds is severe; and it is linked in the minds of many producers with greater yield per area which quite often is a mistaken belief in weed free situations (SEDGLEY, 1991).

Height and leafiness are important characteristics for individual plants to succeed in mixed communities and natural environments. However, in most modem production environments plants are sown in a dense monoculture. In this scenario, the tallest plants may suffer grain loss or collapse because of wind damage. The tendency of the crop to lodge leads to a disorganized light profile, reduced grain production, and harvest problems. Moreover, the tallest plants tend to have reduced harvest index (ROSIELLE \& FREY, 1975; DONALD \& HAMBLIN, 1976). Finally, leafiness and strong competitive ability may be associated with heavy water use, prolonged growth, and lateness in maturity (DONALD \& HAMBLIN, 1983).

The possible antagonism between competitive ability and productivity per area in intensive production environments led DONALD (1968) to propose the concept of a "weak competitor" by which a successful crop ideotype for high plant population would be a weak competitor relative to its mass. It would make a minimum demand on resources per unit of dry matter and would therefore compete to a minimum degree with its like neighbors in the crop community.

Two traits that may be modified to reduce competition in densely populated communities are plant height and leaf number. Theoretically, with a smaller and less leafy plant, the level of interference of each individual with others should be lower. Thus, more individuals can be planted per unit of land area and fewer inputs per plant should be required. Reduced investment in dry matter to form morphological structures such as stems and leaves, should result in great resource availability for grain production, leading consequently to increased harvest Index.
There are two main ways which plant can impact height and leaf number through plant breeding: using specific dwarfing genes that promote reduction in intenode length; and selecting for earliness. The objective of this experiment was to compare dry matter accumulation and partitioning of five maize genotypes with contrasting plant height and leaf number at different plant populations. The basic hypothesis was that reduction in height and leafiness would reduce production and maintenance costs (e.g., water, nutrients and assimilates) per individual, increasing plant efficiency in allocating dry matter to grain.

\section{MATERIALS AND METHODS}

The experiment was performed during the growing season of 1994 in Ames, lowa, US. Study site soil was a Nicollet loam (Fine-loamy, mixed, mesic Aquic Hapludoll). The experimental design was a split plot with main plots arranged in randomized complete blocks. Each treatment was replicated four times. In the main plot, five genotypes were evaluated: one full season hybrid adapted to Central Iowa (Northrup king 4525), one short season hybrid adapted to nor them Minnesota (Car gill 1070) and three lines, 156-A, 117-A and 302-E, containing, respectively, the homozygous recessive dwarfing genes $d_{3}, b_{2}$ and $d_{1}$. Four plant populations were tested in the split-plot: 25,000, 50.000, 75.000 and 100.000 plants.ha ${ }^{-1}$. Each slit plot was constituted by four $6 \mathrm{~m}$ rows, spaced 0.50 $\mathrm{cm}$ equidistantly. No lime, phosphorus or potassium were applied before installing the trial due to the high fertility level of the experimental area $(\mathrm{pH}=$ $6.9,39 \mathrm{ppm}$ of $\mathrm{P}_{2} \mathrm{O}_{5}$ and $170 \mathrm{ppm}$ of $\mathrm{K}_{2} \mathrm{O}$ ). Elemental nitrogen at the rate of $157 \mathrm{~kg}$. ha ${ }^{-1}$ was incorporated into the soil nearly two weeks before planting.

The experiment was hand-planted on May 3, 1994. Strings with marks at the pre-established distances between bordering plants within the row were used to assure the correct planting pattem for each treatment. Three seeds were dropped for each mark of the string. Three weeks after emergence the population was thinned to desired values.

Measurements of dry matter accumulation and partitioning were taken on plants from the two central rows of each split plot. Leaf area and leaf area Index were estimated by the method of BURREN $\boldsymbol{e t}$ al. (1974) and TOLLENAAR (1992). At the slinking stage of each genotype, length and maximum width of every leaf of five random plants were measured. The area of each leaf (A) was estimated by the formula: $A=0.75 \mathrm{x}$ length $\mathrm{x}$ width to obtain total leaf area per plant and leaf area Index (LAI). 
In order to estimate dry matter accumulation and partitioning, five plants were randomly selected and cut at the base of the stem after leaves had senesced entirely. The samples were separated into ears and stover. Samples were dried and ears were weighed, dehusked and shelled. Values for dry matter of the stover (stem + leaves + tassel), ear (including husks), cobs + husks, and grains were recorded and expressed subsequently on an individual plant basis. Total dry matter produced per plant was calculated adding stover plus ear dry matter and dividing the final value by five. Harvest Index $(\mathrm{Hl})$ was estimated as the ratio between dry matter of the grain and the total dry matter of the plant. Grain dry matter produced per unit of leaf área and per unit of LAI production was calculated at the beginning of grain filling.

Analysis of variance was performed and the values for main treatment effects and their interactions were considered significant at the 0.05 level. To provide better understanding of the main effects and their interactions, orthogonal contrasts were calculated. The genotype effect was divided into four contrasts: a) hybrids $\mathrm{x}$ dwarves; b) full season hybrid $\mathrm{x}$ short season hybrid; c) tillering dwarf (302-E) x non-tillering dwarves; d) nontillering dwarf $1 \mathrm{x}$ non- tillering dwarf 2 . The density effect was divided into linear and quadratic effects. A regression analysis was performed for the significant contrasts involving the interaction between genotypes and plant populations. The equations that gave higher coefficients of determination, and that better explained the biological behavior of each variable, were chosen to summarize the results.

\section{RESULTS}

Stover dry matter reacted differently among cultivars to the increase in plant population (Figure IA). The most sensitive cultivar was the dwarf 302-E, which decreased by 58 grams the dry matter allocated to leaves, stem, and tassel for each increment of 25,000 pi. ha $^{-1}$ in plant population. Stover dry matter of the short season hybrid (C 1070) and the dwarf 156-A was less sensitive to shifts in plant population. The long season hybrid (NK 4525) variated stover dry matter more with increase in plant population than the short season hybrid.

Regardless of plant population, hybrids produced at least two times more ear dry matter than dwarves (Figure 1 B). On an absolute basis, hybrids had larger decreases in ear dry matter with increase in population than the dwarves. However, if the comparison is made on a relative basis, the percentage reduction was almost the same. At 100,000pl. ha ${ }^{-1}$ hybrid ear dry matter was about $55 \%$ of that at 25,000 pi. ha ${ }^{-1}$, whereas the dwarves allocated $54 \%$ of the dry matter produced at 25,000pl. ha ${ }^{-1}$ when sown at the highest plant density.

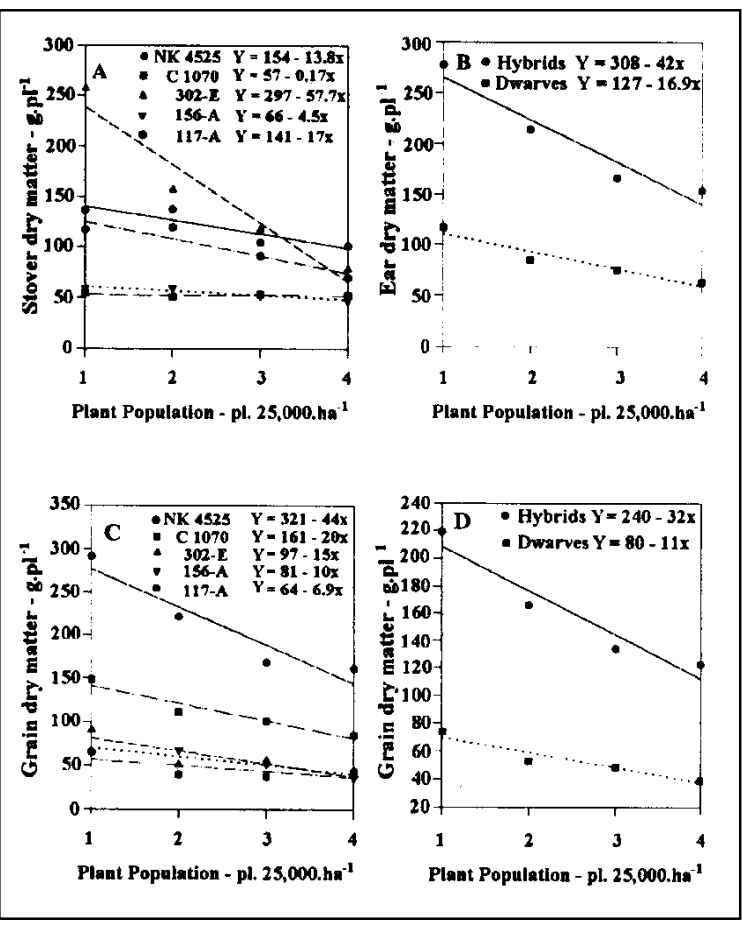

Figure 1 - Stover (A), ear (B) and grain (C, D) dry matter os a full season hybrid (NK 4525), a short season hybrid (C 1070) and three dwarf lines (302-E, 156-A, and 117A), at plant populations ranging from 25,000 (1) to 100,000 (4) plants . ha ${ }^{-1}$, Ames, Iowa, US, 1994

Three levels of decrease in grain dry matter production per plant were observed among cultivars when plant density rose from 25,000 to 100,000pl. ha ${ }^{-1}$ (Figure 1 C). The full season hybrid had the largest values and also the sharpest decreases with increasing plant population. Competition among plants was apparently lower for the short season hybrid and the absolute rate of decrease in grain dry matter per plant was less than half of that of the long season hybrid. Dwarf lines maintained kernel dry matter per plant relatively constant across the range of plant densities used in the experiment. Hybrids lost grain production per plant at a rate three times greater than dwarves with increasing plant population (Figure $1 \mathrm{D})$, but they also produced much more grain dry matter per plant at any given density. Even though the decrease in yield 
production per plant in absolute values was much greater for hybrids than for dwarves, in relative terms both groups of cultivars yielded about $56 \%$ of the production obtained at the lowest plant population when sown at $100,000 \mathrm{pl} . \mathrm{ha}^{-1}$.

For all. Materials, with the exception of dwarf 156-A, biomass per plant decreased linearly with increase in population (Figure 2A). Rate of decrease in dry matter produced per plant was more accentuated for the full season than for the short season hybrid. Total dry matter produced per plant of the tillering dwarf $302-\mathrm{E}$ was more sensitive to the increase in plant population than biological yield of non-tillering dwarves (Figure $1 \mathrm{~B}$ ). When biological yield was analyzed on an area basis, a different response pattem was observed, with all materials increasing biomass production with increase in plant population (Figures 2C and 2D). Rate of increase of total dry matter production per area of hybrids was 2. L times larger than for dwarves, within the range of densities tested in the experiment (Figure 2D). As a consequence of this substantial difference in the slopes, hybrids had $43 \%$ and $80 \%$ greater biological yield than the dwarves at the lowest and highest populations, respectively.

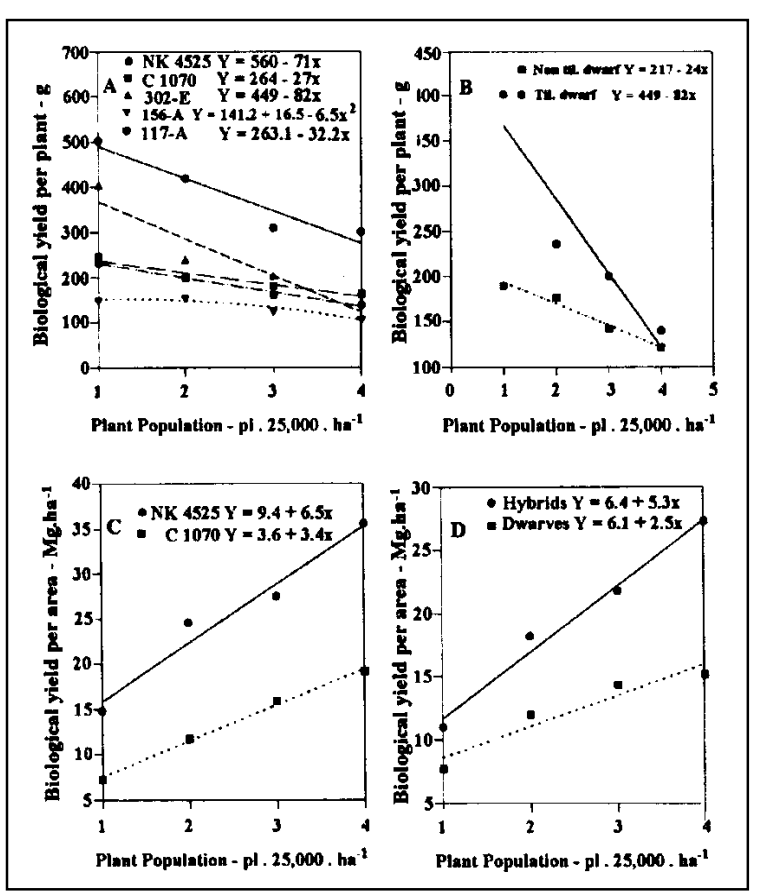

Figure 2 - Biological yield per plant (A, B) and per area (C, D) of a full season hybrid (NK 4525), a short season hybrid (C 1070) and three dwarf lines (302-E, 156-A, and 117-A), at plant populations ranging from 25,000 (1) to 100,000 (4) plants . ha ${ }^{-1}$, Ames Iowa, US, 1994.
Harvest Index was one of the few variables that were not affected significantly by the interaction between cultivars and plant density. There was a remarkable difference among genotypes in their ability to allocate dry matter to grain. Hybrids had similar harvest Indices, both allocating $52.5 \%$ of their total biomass to grain. Dwarves were less efficient than hybrids, showing an average harvest Index of $30.5 \%$. Plant density did not significantly impact this variable.

The increase in plant population affected cultivar leaf area at flowering differently (Figure 3A). Car gill 1070 and dwarf 156-A did not vary leaf area very much with plant density. NK 4525 and 117-A lost about $300 \mathrm{~cm}^{2}$ of green leaf area per plant for each increment of 25,000pl. ha ${ }^{-1}$. Dwarf 302-E showed the highest leaf area per plant. It also had the greatest sensitivity to crowding, losing more than $3,000 \mathrm{~cm}^{2}$ of leaf area for each increase of $25,000 \mathrm{pl}$. $\mathrm{ha}^{-1}$. LAI of cultivars, excepting $302-\mathrm{E}$, responded linearly to increased plant population (Figure 3B). Increments of LAI per unit plant density were not very different, ranging from 0.72 to 1.07 . Dwarf 302-E always had the largest values of leaf area Index at all plant densities tested. In contrast, the short season hybrid had the smallest absolute values of LAI and the lower rates of increase of this variable with population.
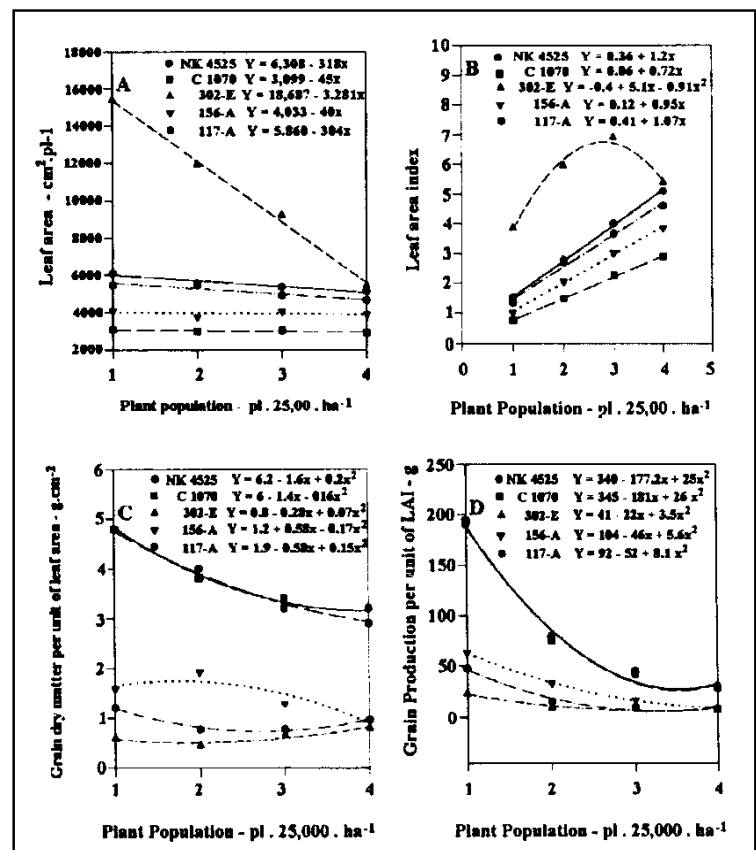

Figure 3 - Leaf area - LA (A), leaf area index - LAI (B), grain production per unit of LA (C) and LAI (D) of a full season hybrid (NK 4525), a short season hybrid (C 1070) and three dwrf lines (302-E, 156-A, and 117-A), at plant populations, ranging from 25,000 (1) to 100,000 (4) plants . ha ${ }^{-1}$, Ames Iowa, US, 1994. 
Hybrids had very similar trends in terms of grain dry matter produced per unit leaf area and LAI (Figures 3C and 3D). There was a greater rate of decrease in both parameters for hybrids than for dwarves when the population increased from 25,000 to $100,000 \mathrm{pl}$. ha ${ }^{-1}$. Even though they had larger rates of grain dry matter loss per unit of photosynthetic tissue, hybrids had much larger ratios than dwarves across all range of populations tested, producing 4.2 times more grain per $\mathrm{cm}^{2}$ of leaf area at $25,000 \mathrm{pl}$. ha ${ }^{1}$ and 3.36 times more at the highest population.

\section{DISCUSSION}

As population levels increased, so did interplant competition for resources, promoting a decrease in total dry matter produced per plant for all cultivars (Figure 2A). Reduction of stover, ear and grain dry matter resulted as plant density increased, contributing to decrease biological yield on an individual plant basis (Figures IA, 1 B, and 1 C). The same response was observed by TETIOKAGHO \& GARDNER (1988), who estimated a decrease of 20 to $50 \%$ in photomaps per plant as population increased from 3.5 to 6.3 plants. $\mathrm{M}^{-2}$, depending on genotype. In the present study, cultivars that had greatest biological yield at low plant populations (NK 4525 and 302-E) also showed steeper decreases in biomass per plant as population increased (Figure 2.A).

On the other hand, when total photomaps was expressed per unit ground area, an opposite trend was detected. Materials that showed the greatest loss of total dry matter on an individual plant basis were also those that expressed the greatest increase when the same variable was considered on an area basis (Figures 2C and 2D). The addition of more plants per area offset the decrease in dry matter per plant and the flam result was a linear increase in biological yield per hectare with density. Furthermore, the higher absolute values of total dry matter per plant of the full season hybrid in relation to the short season hybrid, or by the hybrids in relation to the dwarves, at any plant density, compensated for their sharper losses of photomaps per plant as population increased. These antagonistic trends, varying with the scale considered, emphasize the general principle of crop physiology that crop plants function as individual organisms within stands. The goal of optimizing production per unit land area requires that plants be grown under population densities that preclude maximum individual expression.

At lower plant densities, the tillering ability of 302-E was not an efficient mechanism to improve grain yield in comparison to the other genotypes (Figure 1 C). The ability to produce viable tillers has been important for some species in the grass family, such as rice and Sorghum, by providing a buffer that prevents grain yield from dropping too much when plant population is below optimum (GARDNER $\boldsymbol{e t}$ al., 1985). Even in maize, there is some evidence that tillering, as well as prolificacy, may contribute to reproductive plasticity and greater yield stability in dry environments (MUENCHRATH, 1995). In the present study, the tillering ability of 302-E was an important mechanism to improve biomass per plant at the lower plant populations, especially in comparison to the dwarf lines (Figure 2A). However, most of this dry matter was allocated to leaves, stems and lassies (Figure IA). Indeed, 302-E showed the highest values of leaf area and leaf area Index (Figure 3A and 3B) and the lowest value of grain dry matter per unit of photosynthetic tissue (Figures 3C and 3D) at the lowest plant populations.

Values of leaf area per plant for dwarf 302- $\mathrm{E}$ at the lowest population used in the experiment (Figure 3A) were much higher than have been reported by NUNEZ \& KAMPRATH (1969), BROWN et al. (1970), and TETIO-KAGHO \& GARDNER (1988). It is possible that part of the difference is due to the method used to estimate leaf area of the tillering line. Since it frequently produced several tillers per plant, it was difficult and time consuming to measure all leaves in all the tillers, particularly at low plant populations. Therefore, the alterative used was to measure only leaves of the main stem plus one tiller that appeared to be representative of the mean of all tillers. Final leaf area of the tillers was calculated indirectly, by multiplying the value of the measured tiller by the number of tillers produced. Is seems that this indirect approach overestimated real values, particularly when 302-Ehad enough ground area available for producing a high number of tillers. At the highest plant populations the problem was minimized because tillering was largely suppressed and all leaf area calculations were based on actual individual leaf measurements.

Contrary to previous observations, plant density did not significantly influence the harvest Index of the genotypes used in the experiment. DELOUGHERY et al. (1979) and GENTER \& CAMPER (1973) found that the amount of dry grain, in relation to total dry mass, decreased as plant density increased, or as maize encountered greater stress, due to an increase in barrenness. In the present study, both biological yield and grain production per plant decreased by approximately the same magnitude when 
population was increased from 25,000 to 100,000 pl.ha ${ }^{-1}$, so that final values of harvest Index of each cultivar did not change very much with plant population (Figures 2A and $1 \mathrm{C}$ ). It is likely that the favorable edaphically and weather conditions verified during the trial helped plants to balance vegetative and reproductive growth.

Even though dwarf plants had slower absolute rates of grain dry matter loss than hybrids when population was increased (Figure l D), they did not have any advantage over hybrids in terms of harvest Index. Indeed, the percentage of dry matter allocated to grains was significantly lower in the short-stalked materials, regardless of plant density. Therefore, the smaller plant size did not result in greater resource availability for grain production at any plant population. Dwarf lines presented morphological and genetic constraints that limited their efficiency in producing and allocating carbohydrates to grain. Despite their limited plant height $(127 \mathrm{~cm}$ average for the three genotypes and four plant populations), dwarves produced around 20 leaves per plant, and had very short intenode. The resulting dose superposition of leaves on the stem probably prevented adequate penetration of solar radiation into the canopy, increasing interplant competition per light, which in turn may have reduced source potential. Data presented in Figures 3C and 3D, showing lower grain dry matter produced per unit of green leaf area, provide indirect support for the hypothesis of limiting photosynthesis. In addition, it was not possible to obtain any source of dwarf ness in an elite cultivar. The genetic background of the lines included in the trial was based on old inbreeds, such as W23 and M 13 , which are no longer used for hybrid production in the Com Belt.

\section{CONCLUSIONS}

Reducing plant height through recessive dwarfing genes or earliness did not improve grain yield per plant or harvest Index of maize in relation to a fill hybrid adapted to Central lowa, regardless of plant population. Short-stalked materials did lose less total biomass and grain dry matter per plant as plant density increased, which may indicate that interplant competition was lower for such materials at high plant populations. However, their absolute dry matter production was lower than for the normal hybrid, at all plant densities, decreasing overall performance. This indicates that reducing plant height only, without adequate plant architecture (e.g. lower number and better distribution of leaves) and an improved genetic background, is not enough to increase harvest Index of maize under commercial production situations.

\section{REFERENCES}

BROWN, W. R., BEATY, E.R, ETHREDGE, W.J., et al. Influence of row width and plant population on yield of two varieties of com (Zea mays L). Agron J, Madison, v. 62, p. 767-770, 1970.

BURREN, L., MOCK, J.J., ANDERSON., I.C. Morphological and physiological traits in maize associated with tolerance to high plant density. Crop Say, Madison, v. 14, p. 426-429, 1974

DELOUGHERY, R.L, CROOKSTON, R.K. Harvest Index from affected by population density, maturity rating and environment. Agron J, Madison, v. 71, p. 577-580., 1979.

DONALD, C.M. The breeding of crop ideotype. Emphatic, Correct, v. 17, p. 385-403, 1968.

DONALD, C.M., HAMBLIN., J. The biological! yield and harvest Index of cereals as agronomic and plant breeding criteria. Adv Agron, San Diego, v. 28, p. 361-405, 1976.

DONALD, C.M., HAMBLIN, J. The convergent evolution of annual seed crops in agriculture. Adv Agron, San Diego, v. 36, p.97-139, 1983.

FISCHER, R.A., TURNER., N.C. Plant productivity in the arid and semi-arid zones. Ann Rev Plant Physiol, Paio Alto, v. 29 , p. $277-317,1978$

GARDNER, F.P., PEARCE, R.B., MITCHELL, R.L. Physiology of crop plants. Ames: lowa State University, 1985. 478 p.

GENTER, C.F., CAMPER, H.M. Component plant part development in maize as affected by hybrids and population density. Agron J, Madison, v. 65, p. 669-771, 1973.

JENNINGS, P.R. Plant type as rice breeding objective. Crop Say, Madison, v. 4, p. 13-15, 1964.

MUENCHRATH, D.A. Morphological and physiological characterization of a desert adapted traditional native American maize (Zea mays L.) cultivar. Ames - lowa. 187 p. PhD Dissertation, lowa State University, 1995.

NUNEZ, R, KAMPRATH., E Relationships between N response, plant population and row width on growth and yield from. Agron J, Madison, v. 61, p. 279-282, 1969.

PENDLETON, J., SEIF, R.D. Role of plant height in com competition. Crop Say, Madison, v. 2, p. 154-156, 1962

ROSIELLE, A.A., FREY, KJ. Application of restrictions selection Indices for grain improvement in oats. Crop ski., Madison, v. 15,p.544-547, 1975.

SEDGLEY, R.H. An appraisal of the Donald's ideotype after 21 years. Field Crops Revs, Amsterdam, v. 26, p. 93-112, 1991.

TETIO-KAGHO, F., GARDNER, F.P. Responses of maize to plant population density. I. Canopy development, light relationships, and vegetative growth. Agron J, Madison, v. 80, p. $930-935,1988$

TOLLENAAR, M. Is low plant density a stress in maize? Maydica, Bergamo, v. 37, p. 305-311, 1992 